\title{
Validation of Selected Oscillatoriales from Various Indian Coasts through Phenetic and 16S rRNA Gene
}

\author{
T. Bhuvaneshwari, G.V.N.S. Deviram, L. Uma and D. Prabaharan* \\ National Repository for Microalgae and Cyanobacteria (Sponsored by DBT, Govt. of India), \\ Department of Marine Biotechnology, School of Marine Sciences, Bharathidasan University, \\ Tiruchirappalli-620 024, Tamil Nadu, India \\ *Corresponding author
}

\section{A B S T R A C T}

\section{Keywords}

Cyanobacteria; Oscillatoriales; Habitat; Morphology; phylogeny; 16S rRNA

\section{Article Info}

Accepted:

25 June 2016

Available Online:

10 July 2016
Eight strains of filamentous, non heterocystous cyanobacteria of order Oscillatoriales from diverse marine habitats belonging to coastal areas of India had been categorized using phenotypic and phylogenetic characteristics. The study included observations of morphological features under light microscope and the molecular phylogenetic analysis of the $16 \mathrm{~S}$ rRNA gene. The phylogenetic relatedness of the investigated strains corroborated well with morphology based taxonomic groupings. The $16 \mathrm{~S}$ rRNA gene analysis revealed distinct clusters and strengthens the results obtained by traditional morphological methods. A combination of genetic and phenotypic study resolved their taxonomic ambiguities and aids to the precise identification of the chosen filamentous strains.

\section{Introduction}

Cyanobacteria constitute one of the most ecologically diverse groups of organisms inhabiting marine, freshwater and terrestrial habitats (Pandey, 2013). Cyanobacteria are oxygenic photosynthetic prokaryotes with enormous morphological diversity and have developed wide ecological tolerance to temperature, light, salinity, alkalinity and UV irradiation (Peter et al., 2015). Traditional classification of cyanobacteria was based on comparisons of morphological features (Geitler, 1932; Desikachary, 1959; Rippka et al., 1979).
The variability in morphological topographies is an integral measure of the diversity and divergence processes in cyanobacteria of all ecosystems over the world (Komarek, 2010). Since several phenotypic features of many cyanobacteria are influenced by the different environmental or culture conditions, the taxonomic classification is extremely difficult (Komarek and Anagnostidis, 1998). A number of the morphological characters such as gas vesicles (Lehtimaki et al., 2000), unicellular to filamentous transition (Shih et $a l .$, 2013), mucilaginous colony formation 
(Rippka et al., 1979) was apparently arisen and/or been lost several times during the long-term laboratory cultivation, which complicates the identification of cyanobacteria. Thus, the major problem of morphology-based taxonomic assessment lies in their morphological plasticity and the limitation of light microscopy.

Consequently, the classification of cyanobacteria progressed from morphological approach to the most fascinating, updated phylogenetic approach ensuring the prompt identification and description of cyanobacterial taxa. The assessment of the phylogeny of organisms through gene sequence analysis has increased dramatically since the advent of PCR and automated sequencing.

Molecular (phylogenetic) data provide a basic criterion for taxonomic classification and had a great impact on every level of cyanobacterial taxonomy. A number of molecular marker genes have been used to delineate several cyanobacterial taxa. The $16 \mathrm{~S}$ rRNA gene is an informational macromolecule that plays a central role in inferring phylogenetic relationships and in identification of cyanobacteria (Neilan et al., 1997; Nubel et al., 1997).

The 16S rRNA gene is reliable, extensively accepted, gold standard molecular marker because of its universal, structurally and functionally conserved nature (Neilan et al., 1997).

Currently, the vast availability of this gene sequences in the database aids to find closer relative phylogenetic species. Hence, the study is focused on both phenetic and phylogenetic approach of classification among the chosen filamentous cyanobacteria of order Oscillatoriales available in the National Facility for Marine Cyanobacteria (NFMC) to clarify their systematics.

\section{Materials and Methods}

\section{Sources of organisms}

Eight marine filamentous, non heterocystous strains isolated from coastal areas of India were selected for the phylogenetic relationship from the repository of the National Facility for Marine Cyanobacteria (NFMC), Bharathidasan University, Tiruchirappalli, Tamil Nadu, India.

\section{Growth and maintenance}

The axenic cultures of the chosen marine filamentous strains were maintained and grown in ASN III marine synthetic medium (Rippka et al., 1979) with the illumination of white fluorescent light $(14: 10 \mathrm{~h}$ light/dark) at an intensity $2.20 \mathrm{Wm}^{-2}$. During incubation, the cultures were frequently observed under the light microscope for mono- specificity of the cultures. Morphological assessments, DNA extraction were performed from the exponential growth phase cultures.

\section{Morphological Identification}

The morphology of cells and filaments was studied using Leica inverted microscope DMI 3000B and images were documented with Leica digital camera DFC425C. The cell dimensions were measured by Leica application suite software. The morphological identification of strains was based on description proposed by Desikachary (1959), Komarek and Anagnostidis (2005). Taxonomic designations of the studied strains were revalidated in accordance with information gathered during the research.

\section{PCR amplification of $16 S$ rRNA gene region}

Total genomic DNA was extracted from the selected strains using the xanthogenate nucleic acid isolation protocol (Tillett and 
Neilan, 2000). To generate the complete sequence of $16 \mathrm{~S}$ rRNA, the gene was amplified by splitting it into three regions and amplified using different set of primers. Amplification of I region included the forward primer 16S1R-AGA GTT TGA TCC TGG CTC AG and reverse primer 16S740R- TCT ACGCAT TTCACCGCT AC described by Seo and Yokota (2003), II region included the cyanobacterial specific primer CYA-359 F-GGG GAA TTT TCC GCA ATG GG (forward) and equimolar ratio of reverse primer CYA-781 (A) RGAC TAC TGG GGT ATC TAA TCC CAT $\mathrm{T}$ and CYA-781(B) R-GAC TAC AGG GGT ATC TAA TCC CTT T described by Nubel et al (1997) and III region included the forward primer CYA-359 F-GGG GAA TTT TCC GCA ATG GG (Nubel et al., 1997) and reverse primer 16S-1494 R-GTA CGG CTA CCT TGT TAC GAC (Tillet et al., 2001). Amplification was carried out in Eppendorf mastercycler Pro S using GoTaq colorless master mix (Promega, U.S), $0.3 \mu \mathrm{M}$ of each primer and $100 \mathrm{ng}$ of template DNA in a $100 \mu \mathrm{l}$ reaction. The cycling profile included an initial denaturation of $94{ }^{\circ} \mathrm{C}$ for 5 min followed by 30 cycles of denaturation at $94^{\circ} \mathrm{C}$ for $1 \mathrm{~min}$, annealing (I region-55.5 ${ }^{\circ} \mathrm{C}$, II region- $60^{\circ} \mathrm{C}$ and III region- $56.4^{\circ} \mathrm{C}$ for $1 \mathrm{~min}$ ) and extension at $72^{\circ} \mathrm{C}$ for $1 \mathrm{~min}$ and a final extension at $72^{\circ} \mathrm{C}$ for $7 \mathrm{~min} .10 \mu \mathrm{l}$ of the amplified products of expected fragments of corresponding regions were subjected to $1.5 \%$ agarose gel electrophoresis stained with ethidium bromide are visualized under the UV transilluminator.

\section{DNA sequencing}

The amplified PCR products from 16S rRNA were purified using a QIAquick PCR purification kit (Qiagen, Hilden, Germany) to remove the excess primer and subsequently used as template in sequencing reactions. The primers employed for PCR amplifications were used to determine the sequences on both strands using the DNA cycle sequencing reaction kit. The DNA sequences were obtained with an ABI 310 automated sequencer using the chaintermination method with big-dye terminators (Eurofins Genomics India PVT Ltd). For the sequence data, automated base calls were checked by manual inspection of the electropherograms of both forward and reverse sequences. The base call conflicts were resolved by alignment and comparison of both strands using DNA baser software v 4.3 (DNA baser). Assembled 16S rRNA gene sequences were submitted to find chimera program of the DECIPHER (Wright et al., 2012) which can be directly accessible through a webpage http://decipher.cee.wisc.edu/FindChimeras.h tml.

\section{Phylogenetic analysis}

The 16S rRNA gene sequences of filamentous cyanobacteria chosen in this study were blasted against Genbank nucleotide sequences. The related representative Genbank sequences of each generic groups and the best match from Blastn analysis were chosen as the reference strains. Multiple sequence alignment was done by Clustal X (Thompson et al.,1997) with default parameters. The best-fitting nucleotide substitution model was fixed by testing 24 different models for each dataset in MEGA software version 6 (Tamura et al., 2013). Phylogenetic tree was generated from this alignment using maximum likelihood analysis in MEGA 6. Bayesian information criterion was employed to achieve the most appropriate substitution model for maximum likelihood. The substitution model used in phylogenetic analysis of $16 \mathrm{~S}$ rRNA was Kimura 2 parameter model. Gaps and missing data were treated as complete 
deletion. In all the cases, bootstrap resampling using 1000 replications was performed to assess the statistical significance of the tree branches.

\section{Results and Discussion}

\section{Morphological Identification}

The taxonomy of oscillatorian taxa is challenging due to the lack of conspicuous traits (Anagnostidis and Komarek, 1988; Komarek and Anagnostidis, 2005). Eight filamentous strains of Oscillatoriales from the repository belonging to coastal regions of India were identified morphologically and categorized under the genera as Spirulina, Oxynema, Phormidium and Pseudanabaena (Komarek and Anagnostidis 2005; Chatchawan et al., 2012). The geographical origins and habitat of the organisms applied in this study are listed in Table 1 and Fig. 1 depicts their light micro photographs.

The genus Spirulina are most frequently assigned to one of a few species, Spirulina subsalsa Oersted, Spirulina labyrinthiformis Gomont and Spirulina major Kutzing based on trichome diameter and coil shape regardless of their habitat of origin. Subsequently, halotolerant, euryhaline Spirulina sp. with tightly coiled trichomes from hypersaline waters was reclassified as Halospirulina tapeticola (Nubel et al., 2000). The strain BDU 141021 isolated from stones of Marina Park and water sports complex of Andaman Island was initially assigned as Spirulina subsalsa.

The traditional identification approach of the genera Oscillatoria/Phormidium/Lyngbya is mainly established on the occurrence of sheaths and does not concur with molecular data; therefore it has to be drastically reevaluated (Komarek, 2003). The main morphological and taxonomic markers of species belonging to the genus Phormidium used are: the shapes of cells and filaments, types of end cells and facultative presence of sheaths. The taxonomy of Phormidium is still unclear (Chatchawan et al., 2012), and therefore it's separation into eight groups based on modern criteria was proposed by Komarek and Anagnostidis (2005) and they had validly described 163 species of Phormidium which are reclassified and relocated from the old traditional genera Oscillatoria and Lyngbya, based on various morphological characters. Oxynema is a new genus separated from the traditional Oscillatoria and Phormidium genera attributing by the main distinguishing features of cylindrical trichomes growing often in fasciculate mats, narrowed ends with bent, elongated and distinctly pointed terminal cells, without calyptra. The sheaths are lacking or facultative and diffluent (Chatchawan et al., 2012). Of the eight strains, four strains namely BDU 10251, 70493, 92071and 120161 exhibited rather uniform basic morphological characters and were adjudged to the genus Oxynema.

According to the conventional approach, strain BDU 46241 of the present study was determined previously as Phormidium tenue (Desikachary 1959). The characteristic morphological features observed in BDU 46241 strain were pinkish to brownish red thallus, trichomes straight or somewhat flexous or attenuated towards the apex, 1-2 $\mu \mathrm{m}$ wide, $2.5-5 \mu \mathrm{m}$ long, slightly constricted at the ungranulated cross walls, apical cells rounded or -conical-rounded bent acute without calyptras. A large number of oscillatorialean species with trichomes up to $3 \mu \mathrm{m}$ wide exhibiting little or no motility of the Geitlerian genera: Phormidium, Plectonema and Lyngbya was included and created into a new genus to Leptolyngbya (Anagnostidis and Komarek, 1988; Marquardt and palinska, 2007). Thus, 
Phormidium tenue had been revalidated as Leptolyngbya tenuis mainly based on their trichome size (Komarek and Anagnostidis, 2005).

Two BDU strains 41121 and 70492 were originally determined as Oscillatoria minnesotensis according to the classification system of Desikachary (1959). The characteristic key features defined for Oscillatoria minnesotensis were 2-5 $\mu \mathrm{m}$ width; 2-4 $\mu \mathrm{m}$ long homogeneous cell content, apical cell rounded and Pseudanabaena catenata were $2 \mu \mathrm{m}$ broad; 3 $\mu \mathrm{m}$ long, cells cylindrical, truncated at both ends, blue green, sometimes somewhat brownish (Desikachary, 1959). According to Komarek and Anagnostidis (2005), the morphological features described for Pseudanabaena catenata are cells cylindrical truncate at both ends, 2-6 $\mu \mathrm{m}$ long; cell content homogeneous or clearly differentiated in chromatic and centroplasma without aerotopes (or facultatively with apical gas vesicles and aerotopes; apical cell rounded or slightly conical truncated, without aerotopes; trichome straight, rarely variously bent, flexible, 1.2-2(2.2) $\mu \mathrm{m}$ wide, strongly constricted at the thickened, hyaline, translucent and ungranulated crosswalls, not attenuated at the ends. In present study based advanced light microscopic analysis of both BDU 41121 and 70492 bedelineate clearly that the strains possess cylindrical cells of similar size truncated at both end of cells with granular cell content, clearly differentiated chromatic and centroplasma make it fit to characteristic feature of Pseudanabaena $\mathrm{sp}$. In order to overcome some of these problems and to permit identification of cyanobacteria at the genetic level, phylogenetic analysis of $16 \mathrm{~S}$ rRNA gene sequence have been applied to confirm their generic entity of the investigated strains.

\section{Nucleotide sequences and accession numbers}

The 16S rRNA gene sequences obtained from the present study were submitted to Genbank and their accession numbers were KX452360-KX452367

Table.1 The geographical origins and habitat of the organisms applied in this study.

\begin{tabular}{|l|l|}
\hline Organisms & Geographical origin and Habitat \\
\hline $\begin{array}{l}\text { Halospirulina tapeticola } \\
\text { BDU 141021 }\end{array}$ & $\begin{array}{l}\text { On stones, Marina Park and water sports complex, } \\
\text { Andaman }\end{array}$ \\
\hline Oxynema thaianum BDU 10251 & Backwater/Stagnant on shore, Vedaranyam, Tamil Nadu \\
\hline Oxynema thaianum BDU 70493 & $\begin{array}{l}\text { Stagnant sea water, Kovalam Beach, Chennai, Bay of } \\
\text { Bengal region. }\end{array}$ \\
\hline Oxynema thaianum BDU 91992 & On the sides of boat, Thevara, Kochi, Arabian sea region. \\
\hline Oxynema thaianum BDU 120161 & On muddy soil, Arambol salt pan, Goa coast, Arabian sea. \\
\hline Leptolyngbya tenuis BDU 46241 & $\begin{array}{l}\text { On submerged rocks, Actual sea, Mandabam, Gulf of } \\
\text { Mannar }\end{array}$ \\
\hline $\begin{array}{l}\text { Pseudanabaena catenata } \\
\text { BDU 41121 }\end{array}$ & $\begin{array}{l}\text { On Coral rock, Actual sea, Kurusadai Island, Gulf of } \\
\text { Mannar }\end{array}$ \\
\hline $\begin{array}{l}\text { Pseudanabaena catenata } \\
\text { BDU 70492 }\end{array}$ & $\begin{array}{l}\text { Stagnant sea water, Kovalam beach, Chennai, Bay of } \\
\text { Bengal region }\end{array}$ \\
\hline
\end{tabular}


Fig.1 Bright field photomicrographs: a:Halospirulina tapeticola BDU 141021, b:Oxynema thaianum BDU 10251, c:Oxynema thaianum BDU 70493, d:Oxynema thaianum BDU 91992, e:Oxynema thaianum BDU 120161, f:Phormidium tenue BDU 46241, g:

Pseudanabaena catenata BDU 41121 h: Pseudanabaena catenata BDU 70492. Scale Bar $-10 \mu \mathrm{m}$
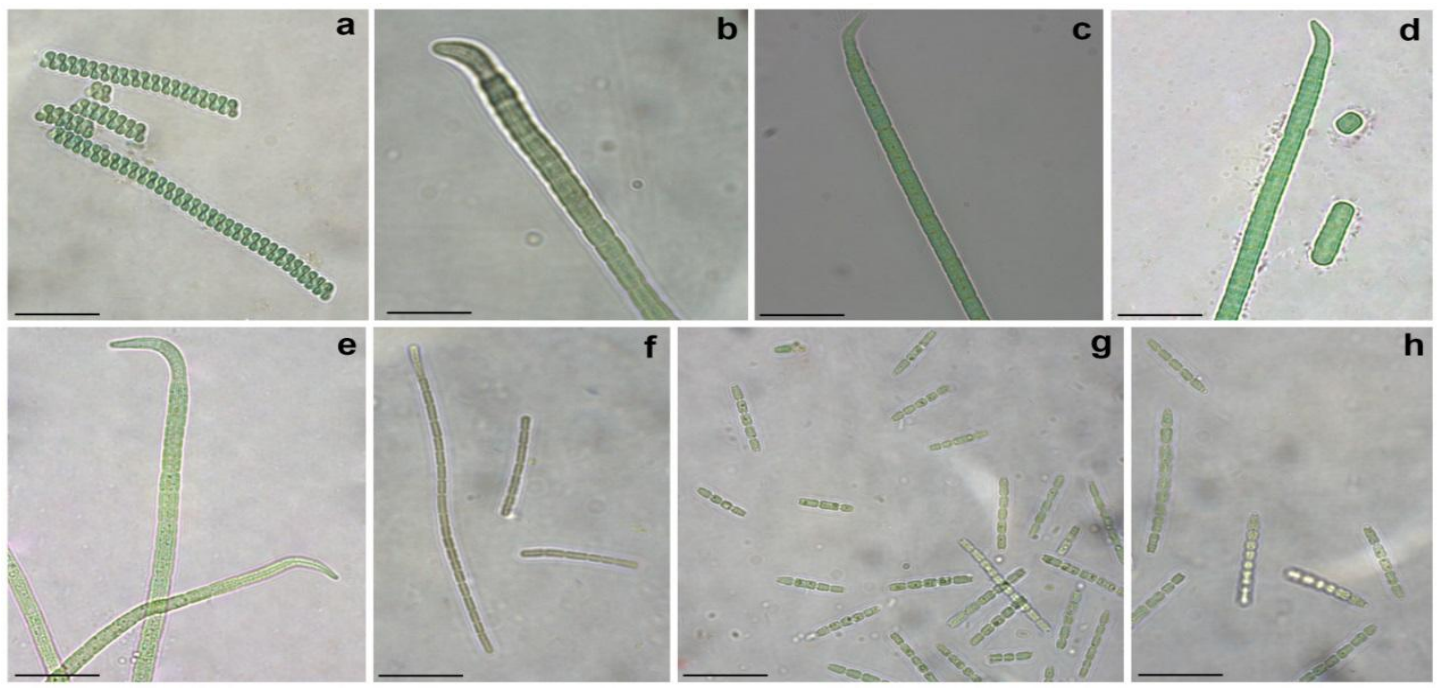

Fig.2 Phylogenetic relationship of marine filamentous cyanobacteria inferred by maximum likelihood analysis of $16 \mathrm{~S}$ rRNA gene sequences. Number at nodes indicates the bootstrap values (1000 replicates) obtained from the analysis. Bootstrap values ( $\geq 50 \%)$ are indicated on the branches. The investigated strains are marked with a black triangle.

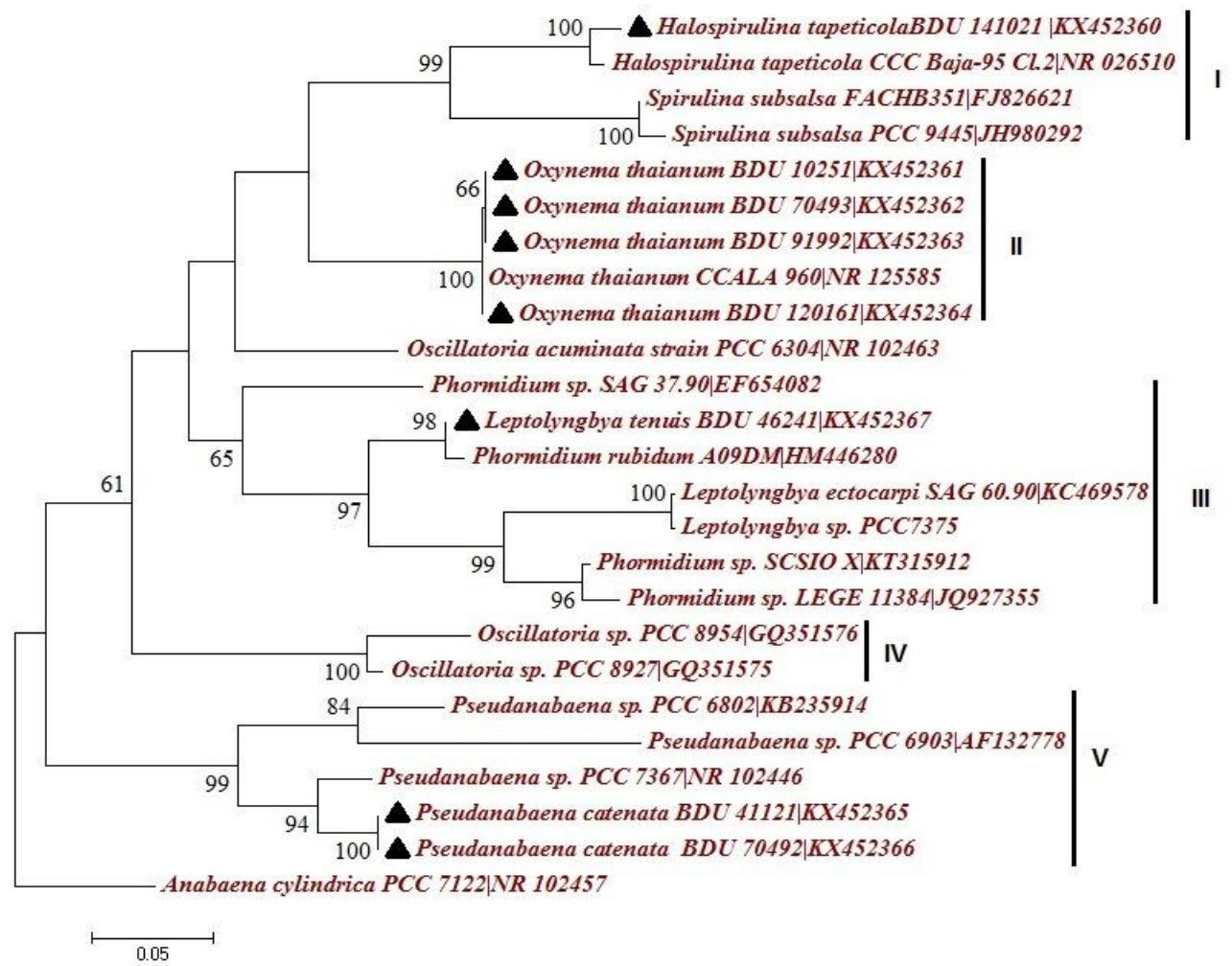




\section{Phylogenetic analysis}

Phylogenetic tree was constructed with nearly complete $16 \mathrm{~S}$ rRNA gene sequence ( 1350 base pairs) of 25 organisms (Fig. 2) using Anabaena cylindrica PCC 7122 as an out group. 16S rRNA gene formed five main clusters in phylogenetic tree. Halospirulina tapeticola BDU 141021 clustered with Halospirulina tapeticola CCC Baja-95 Cl.2 of Pacific Ocean origin with highest bootstrap values while Spirulina subsalsa reference strains retrieved from the public database appeared as sister taxa. BDU 141021 were morphologically similar to Halospirulina tapeticola (Nubel et al., 2000) by their similar trichome width of $1.5-4 \mu \mathrm{m}$, gliding motility and tightly coiled trichomes which confirms their generic epithet as Halospirulina tapeticola. The genus Oxynema thaianum formed a monophyletic group (cluster II) with strains BDU 10251, 70493, 91992, and 120161 isolated from coastal line of Tamil Nadu, Kerala, Konkan coast and the reference Oxynema thaianum CCALA 960 isolated from saltern of Thailand despite their distant geographical origin indicating that it is quite conserved on the DNA level besides to rather similar morphological traits. Leptolyngbya tenuis BDU 46241 isolated from submerged rocks of Gulf of Mannar clustered with Phormidium rubidium A09DM isolated from rocky shore of Gujarat in cluster III containing Leptolyngbya/Phormidium reference strains. This was in agreement with earlier phylogenetic studies, signifying the non-monophyletic nature of Leptolyngbya valderiana (Premanandh et al., 2009). Leptolyngbya tenuis BDU 46241 possessed pinkish to brownish red thallus and very thin trichomes of 1-2 $\mu$ m wide, 2.5$5 \mu \mathrm{m}$ long. Phormidium rubidium A09DM is a phycoerythrin rich organism (Parmar et al., 2011). The clustering of BDU 46241 with Phormidium rubidium A09DM may possibly because of their phycoerythrin nature reflected in 16S rRNA gene. BDU 41121 and 70492 strains previously determined as Oscillatoria minnesotensis falls within the clade of the genus Pseudanabaena in cluster $\mathrm{V}$ with highest bootstrap further authenticates that they belonged to Pseudanabaena catenata.

In summary, a morphological description and phylogenetic placement of the eight investigated strains validly confirm their generic designation and evade typical taxonomic complications.

\section{Acknowledgements}

The authors thank the Department of Biotechnology (Govt. of India)-[Grant No: $B T / P R / 11324 / P B D / 26 / 172]$ and [Grant No: $B T / B I / 04 / 038 / 98(\mathrm{vol} \mathrm{II})]$ for their financial support.

\section{References}

Chatchawan, T., J. Komarek., O. Strunecky., J. Smarda., and Peerapornpisal, Y. 2012. Oxynema, a new genus separated from the genus Phormidium (Cyanophyta). Cryptogamie. Algol., 33:41-59.

Desikachary, T.V. 1959. Cyanophyta I.C.A.R. Monographs on algae. Indian Council of Agricultural Research, New Delhi, India, pp. 77-145.

Geitler, L. 1932. Cyanophyceae. In: Rabenhorst's Kryptogamen - Flora, Akademisches Verlagsgesell schaft, Leipzip .

Komarek, J. 2003. Planktic oscillatorialean cyanoprokaryotes (short review according to combined phenotype and molecular aspects). Hydrobiologia, 502: 367-382.

Komarek, J. 2010. Recent changes (2008) in cyanobacteria taxonomy based on a combination of molecular 
background with phenotype and ecological consequences (genus and species concept). Hydrobiologia, 639: 245-259.

Komarek, J., Anagnostidis, K. 2005 Cyanoprokaryota-2. Teil/2nd Part: Oscillatoriales. In: Budel, B., Krienitz L., Gartner, G., Schagel, M., (Eds.) Susswasser flora von Mitteleuropa 19/2, Elsevier Spektrum, Heidelberg.

Komarek, J., and Anagnostidis, K. 1989. Modern approach to the classification system of Cyanophytes, 4 - Nostocales. Arch. Hydrobiol. Suppl., 82/Algol Stud 56:247-345.

Lehtimaki, J.M., C. Lyra., S. Suomalainen., P. Sundman., L. Rouhiainen., L. Paulin., M. Salkinoja-Salonen and Sivonen, K.2000. Characterization of Nodularia strains, cyanobacteria from brackish waters, by genotypic and phenotypic methods. Int. J. Syst. Evol. Microbiol., 50: 10431053.

Marquardt, J., Palinska, K.A. 2007. Genotypic and phenotypic diversity of cyanobacteria assigned to the genus Phormidium (Oscillatoriales) from different habitats and geographical sites. Arch. Microbiol., 187: 397-413.

Neilan, B.A., D. Jacobs., L.L. Blackall., P.R. Hawkins., P. T. Cox and Goodman, E.A. 1997. rRNA sequences and evolutionary relationships among the toxigenic cyanobacteria of the genus Microcystis. Int. J. Syst. Bacteriol., 47: 693-697.

Nubel, U., F. Garcia-pichel and Muyzer, G. 1997. PCR Primers to Amplify $16 \mathrm{~S}$ rRNA genes from cyanobacteria. Appl. Environ. Microbiol., 63: 3327-3332.

Nubel, U., F. Garcia-Pichel and Muyzer, G.
2000. The halotolerance and phylogeny of cyanobacteria with tightly coiled trichomes (Spirulina Turpin) and the description of Halospirulina tapeticola gen. nov., sp. nov. Int. J. Syst. Evol. Micr., 50: 1265-1277.

Pandey, V.D. 2013. Rock-dwelling cyanobacteria: survival strategies and biodeterioration of monuments. Int. J. Curr. Microbiol. App. Sci., 2: 519-524.

Parmar, A., N.K. Singh., A. Kaushal., S. Sonawala and Madamwar, D. 2011. Purification, characterization and comparison of phycoerythrins from three different marine cyanobacterial cultures. Bioresour. Technol., 102: 1795-1802.

Premanandh, J., B. Priya., D. Prabaharan and Uma, L. 2009. Genetic heterogeneity of the marine cyanobacterium Leptolyngbya valderiana (Pseudanabaenaceae) evidenced by RAPD molecular markers and 16S rDNA sequence data. J. Plankton. Res., 31: 114111150.

Rippka, R., J. Deruelles., J.B. Waterbury, M. Herdman and Stainer. R.Y., 1979. Generic assignments, strain histories and properties of pure cultures of cyanobacteria. J. Gen. Microbiol., 111: 1-61.

Seo, P.S., Yokota, A. 2003. The phylogenetic relationships of cyanobacteria inferred from $16 \mathrm{~S}$ rRNA, gyrB, rpoC1, and rpoD1 gene sequences. J. Gen. Appl. Microbiol., 49: 191-203.

Tamura, K., G. Stecher., D. Peterson., A. Filipski and Kumar, S. 2013. MEGA6: Molecular evolutionary genetics analysis version 6.0. Mol. Biol. Evol., 30: 2725-2729.

Thompson, J.D., T.J. Gibson., F. Plewniak., 
F. Jeanmougin and Higgins, D.G. 1997. The ClustalX windows interface: flexible strategies for multiple sequence alignment aided by quality analysis tools. Nucleic. Acids. Res., 25: 4876-4882.

Tillett, D., Neilan, B.A. 2000. Xanthogenate nucleic acid isolation from cultured and environmental cyanobacteria. $J$. Phycol., 36: 251-258.

Wright, E.S., L.S. Yilmaz and Noguera, D.R. 2012. DECIPHER, a searchbased approach to chimera identification for $16 \mathrm{~S}$ rRNA sequences. Appl. Environ. Microbiol., 78: 717-725.

\section{How to cite this article:}

Bhuvaneshwari, T., G.V.N.S. Deviram, L. Uma and D. Prabaharan. 2016. Validation of Selected Oscillatoriales from Various Indian Coasts through Phenetic and 16S rRNA Gene. Int.J.Curr.Microbiol.App.Sci. 5(7): 944-952. doi: http://dx.doi.org/10.20546/ijcmas.2016.507.106 